\title{
Religiusitas, Kepercayaan pada Aparat, Tingkat Pendidikan, Pengetahuan Perpajakan dan Kepatuhan Wajib Pajak
}

\author{
Priscilla Octavianny ${ }^{1}$ \\ Fakultas Ekonomi dan Bisnis \\ Universitas Negeri Malang, Indonesia
}

\author{
Makaryanawati ${ }^{2}$ \\ Fakultas Ekonomi dan Bisnis \\ Universitas Negeri Malang, Indonesia
}

\author{
Ferby Mutia Edwy ${ }^{3}$ \\ Fakultas Ekonomi dan Bisnis \\ Universitas Negeri Malang, Indonesia
}

Surel : priscillaoctavianny@gmail.com

\section{ABSTRAK}

Tujuan penelitian ini adalah untuk mengetahui pengaruh religiusitas, kepercayaan aparatur, tingkat pendidikan dan pengetahuan perpajakan terhadap kepatuhan Wajib Pajak Orang Pribadi Bukan Pegawai. Penelitian ini dilakukan di KPP Pratama, Malang Selatan. Jumlah sampel dalam penelitian ini sebanyak 100 responden dengan metode pengambilan sampel menggunakan metode accidental sampling. Pengumpulan data dilakukan melalui kuesioner. Teknik analisis data yang digunakan dalam penelitian ini adalah regresi linier berganda. Berdasarkan hasil analisis dapat diketahui bahwa religiusitas, kepercayaan pada aparatur, tingkat pendidikan dan pengetahuan perpajakan berpengaruh positif terhadap kepatuhan wajib pajak.

Kata Kunci: $\quad$ Pemenuhan pajak; Religiusitas, Kepercayaan pada Aparatur; Tingkat Pendidikan; Pengetahuan Pajak.

\section{Religiosity, Trust in Apparatus, Level of Education, Tax Knowledge and Taxpayer Compliance}

\begin{abstract}
The purpose of this study is to determine the effect of religiosity, trust in the apparatus, education level and tax knowledge on Non-Employee Individual Taxpayer compliance. This research was conducted at KPP Pratama, South Malang. The number of samples in this study were 100 respondents with a sampling method using accidental sampling method. Data collection is done through questionnaires. The data analysis technique used in this research is multiple linear regression. Based on the results of the analysis it can be seen that religiosity, trust in the apparatus, education level and tax knowledge have a positive effect on tax compliance.
\end{abstract}

Keywords: $\quad$ Tax Compliance; Religiosity, Trust in The Apparatus; Education Level; Tax Knowledge.

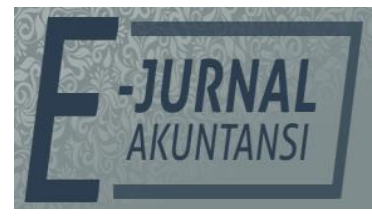

e-ISSN 2302-8556

Vol. 31 No. 1

Denpasar, Januari 2021

Hal. 77-91

DOI:

10.24843/EJA.2021.v31.i01.p06

PENGUTIPAN:

Octaviany, P. Makarynawati, \& Edwy, F.M. (2021). Religiusitas, Kepercayaan pada Aparat, Tingkat Pendidikan, Pengetahuan Perpajakan dan Kepatuhan Wajib Pajak. EJurnal Akuntansi, 31(1), 77-91

RIWAYAT ARTIKEL: Artikel Masuk: 13 Juli 2020 Artikel Diterima: 20 Januari 2021

Artikel dapat diakses : https://ojs.unud.ac.id/index.php/Akuntansi/index 


\section{PENDAHULUAN}

Sumber penerimaan terbesar dalam Anggaran Pendapatan Belanja Negara (APBN) ialah pajak. Dalam postur APBN 2019, penerimaan perpajakan tercatat menyumbang 82,5 persen dari total pendapatan negara (pajak.go.id). Peran penerimaan pajak bagi negara menjadi sangat dominan dalam hal dukungan terhadap pemerintah dan terus meningkat dari tahun ke tahun. Namun dalam praktiknya, penerimaan negara dari pajak masih belum optimal (Sondakh, 2017). Kontribusi penerimaan pajak terhadap APBN cukup fluktuatif karena adanya peningkatan dan juga penurunan. Penerimaan pajak dari tahun 2015-2018 mengalami sebagai berikut. Pada tahun 2016 penerimaan pajak mengalami peningkatan sebesar 3,95\% dari tahun 2015, sedangkan tahun 2017 mengalami penurunan sebesar 1,4\% dari tahun 2016, dan pada tahun tahun 2018 kembali mengalami peningkatan sebesar 0,6\% dari tahun 2017 (www.bps.go.id). Peningkatan penerimaan pajak merupakan keberhasilan dari optimalisasi pemungutan perpajakan.

Tahun 1983 terjadi revolusi pajak dimana sistem pajak berubah dari Official assessment system menjadi self assessment system sampai saat ini. Self assessment system adalah kepercayaan penuh yang diberikan pihak Fiskus kepada Wajib pajak dalam menghitung, memperhitungkan, melaporkan dan membayar pajak. Self assessment system sangat berkaitan dengan motivasi yang mendukung perilaku Wajib Pajak untuk menciptakan kepatuhan Pajak. Menurut (Dwi \& Renny, 2017) Wajib Pajak dapat dikatakan patuh jika wajib pajak tidak melanggar disiplin dan menerapkan peraturan perpajakan yang ada. Salah satu kriteria kepatuhan Wajib Pajak ialah ketepatan waktu dalam melaporkan Surat Pemberitahuan (SPT).

Kepatuhan Wajib Pajak dalam ketepatan pelaporan SPT didukung oleh motivasi pribadi untuk melaksanakan kewajibannya terhadap negara. Terdapat dua faktor yang mempengaruhi motivasi Wajib Pajak yakni faktor motivasional dan faktor hygiene (Noermijati, 2013). Faktor motivasional atau intrinsik berkaitan dengan religiusitas, kepercayaan pada aparat dan pengetahuan perpajakan sedangkan faktor hygiene atau ekstrinsik berkaitan dengan tingkat pendidikan Wajib Pajak.

Motivasi intrinsik kepatuhan pajak terbentuk atas dasar ajaran agama karena Konstitusi Negara Indonesia didasarkan atas keyakinan pada Ketuhanan Yang Maha Esa. Jumlah penganut agama di Indonesia meliputi: Agama Islam sebesar 87,2\%, Protestan 6,9\%, Katolik 2,9\%, Hindu 1,7\%, Buddha 0,7\% dan Konghucu sebesar 0,05\% dari jumlah masyarakat di Indonesia (indonesia.go.id). Pada tahun 2018, Indonesia merupakan negara terbanyak kedua yang memberangkatkan jamaah Umroh setelah negara Pakistan, dengan jumlah 1.005.802 jamaah (www.msn.com). Kedua hal tersebut menunjukkan bahwa Indonesia merupakan negara religius. Semua agama di Indonesia mengajarkan kebaikan dan patuh terhadap peraturan negara (Ermawati \& Afifi, 2018). Hasil penelitian yang dilakukan oleh Torgler (2007) menunjukkan bahwa religiusitas berpengaruh secara positif terhadap moral pajak dan meningkatkan kepatuhan pajak. Sedangkan penelitian oleh Widagsono (2017) di Kota Malang menghasilkan kesimpulan bahwa religiusitas tidak berpengaruh positif terhadap Variabel Kepatuhan Wajib Pajak. 
Motivasi intrinsik juga berkaitan dengan kepercayaan pada aparat. Kepercayaan pada aparat pajak didefinisikan sebagai suatu ekspektasi wajib pajak terhadap ucapan dan tindakan aparat pajak yang dapat diandalkan dalam melayani, membantu atau menyiapkan segala keperluan yang dibutuhkan wajib pajak (Ariani, 2016). Torgler (2007) menyatakan bahwa kepercayaan terhadap pemerintah, sistem hukum, lembaga peradilan dan pejabat pemerintah berpengaruh positif terhadap moralitas pajak yang mendukung kepatuhan pajak. Indonesia melaksanakan sistem demokrasi yang diimbangi dengan rule of law sebagai pilar keadilan dan kepercayaan terhadap aparat (Asshiddiqie, 2010). Ratmono \& Cahyonowati (2016) menyatakan bahwa tingkat kepercayaan pada otoritas pajak berpengaruh positif dan signifikan terhadap tingkat kepatuhan Wajib Pajak. Sedangkan, hasil penelitian (Siahaan, 2005) menyimpulkan bahwa kepercayaan kepada aparat pajak tidak berpengaruh terhadap kepatuhan wajib pajak.

Pasaribu \& Tjen (2016) menyatakan bahwa orang yang memiliki pendidikan yang lebih tinggi akan lebih mengetahui peraturan pajak dan kebijakan fiskal serta mengetahui cara-cara untuk menghindari pajak. Wajib Pajak dengan tingkat pendidikan yang tinggi akan lebih menguasai dan lebih memahami Undang-undang Perpajakan yang berlaku, sehingga tidak menutup kemungkinan membuat Wajib Pajak melakukan tindakan curang yang melanggar aturan guna memperkecil pajak yang dikenakan negara. Yustina et al. (2019) menyatakan bahwa tingkat pendidikan positif dan signifikan terhadap kepatuhan pajak. Berbeda dengan penelitian Manalu et al. (2016) memberikan hasil bahwa tingkat pendidikan tidak berpengaruh terhadap kepatuhan Wajib Pajak.

Pengetahuan perpajakan merupakan ilmu yang dimiliki oleh Wajib Pajak mengenai tata cara perpajakan, sistem dan fungsi perpajakan serta tentang kewajiban perpajakan. Pengetahuan pajak disalurkan melalui pendidikan formal maupun informal. Wajib Pajak yang mengetahui kewajiban perpajakan maka akan berusaha untuk mematuhi peraturan perpajakan. Jika memang Wajib Pajak ingin memperkecil beban pajak yang ditanggung maka akan melakukan perencanaan pajak yang baik sesuai dengan hukum yang berlaku (Faisal, 2009). Ghoni (2012) menyimpulkan bahwa pengetahuan perpajakan berpengaruh positif terhadap kepatuhan wajib pajak daerah karena wajib pajak memiliki kemampuan dalam menghitung besarnya kewajiban pajak yang ditanggung, sehingga tidak ada yang merasa dirugikan. Pengetahuan pajak yang benar akan memotivasi Wajib Pajak untuk patuh dan jujur.

Di kota Malang, penelitian mengenai kepercayaan pada aparat masih jarang dilakukan. Penelitian di Kota Malang lebih mengacu kepada kualitas pelayanan aparat pajak. Penelitian mengenai kepatuhan pajak di KPP Pratama Malang Selatan karena pada bulan April tahun 2018 hanya sebesar 42,62\% Wajib Pajak Orang Pribadi Non Karyawan yang membayar kewajiban pajaknya dan terjadi penurunan secara nominal dalam penerimaan realisasi pajak sebesar $24 \%$ dibandingkan tahun sebelumnya (www.malangtimes.com). Berdasarkan uraian, memumculkan keingintahuan peneliti untuk mendalami dan mencari tahu lebih dalam kepatuhan pajak Wajib Pajak Orang Pribadi Non Karyawan di KPP Pratama Malang Selatan. 
Teori motivasi dua faktor dikembangkan oleh Frederic Herzberg dan rekan-rekan pada tahun 1959, yang bertujuan untuk mencari tahu hal-hal yang menjadi motivasi seseorang melakukan sebuah tindakan (Noermijati, 2013). Herzberg mengembangkan teori yang dikenal dengan teori dua faktor. Kedua faktor meliputi faktor intrinsik-ekstrinsik atau dikenal dengan faktor motivatorhygiene.

Faktor motivator bersifat intrinsik yang merupakan acuan seseorang untuk berperilaku. Aspek-aspek motivator meliputi: pencapaian, pengakuan/ penghargaan dan tanggung jawab. Terpenuhinya aspek dari dalam diri tersebut menyebabkan orang merasa puas. Faktor motivator dalam kepatuhan pajak terbentuk dari ajaran agama atau religiusitas, kepercayaan pada aparat dan pengetahuan perpajakan yang dimiliki Wajib Pajak. Agama mengajarkan kebaikan untuk taat kepada negara, salah satunya taat akan kewajiban perpajakan. Kepercayaan pada aparat dan pengetahuan perpajakan yang benar akan mendukung Wajib Pajak berperilaku jujur dan patuh terhadap sistem hukum perpajakan yang berlaku.

Religiusitas berkaitan dengan kepercayaan individu terhadap agama yang dipeluknya. Salah satu ajaran agama yaitu memberikan sebagian hartaya kepada pihak yang berhak menerimanya, terutama dalam pelaksanaan yang diatur oleh negara. Menurut Bayinah (2015) menyatakan bahwa 96\% masyarakat memberi sumbangan karena didasari oleh kepercayaan dan ajaran agama yang dianutnya. Indikator penelitian ini berlandaskan pada keaktifan, pengetahuan dan keyakinan yang memotivasi Wajib Pajak secara moral untuk berkontribusi terhadap pajak. Religiusitas mendasari perilaku seseorang untuk taat menjalankan kewajibannya sebagai umat beragama kepada negara dengan melaporkan maupun membayar pajak secara benar dan tepat waktu.

Religiusitas membentuk faktor motivasional Wajib Pajak untuk taat kepada negara dengan patuh terhadap perpajakan. Berkaitan dengan pemungutan pajak, agama apapun yang dianut oleh Wajib Pajak tidak mengajarkan untuk melakukan penghindaran pajak (Widodo, 2010). Kepatuhan pajak yang tinggi akan mensejahterakan kehidupan sosial sehingga akan membangun negara ke arah yang lebih baik.

Religiusitas yang berkaitan dengan agama berperan penting dalam membantu Direktorat Jenderal Pajak merealisasikan bahkan meningkatkan target penerimaan pajak. Religiusitas memotivasi perilaku positif yang sesuai dengan ajaran nilai agama untuk mencegah perilaku negatif. Ajaran agama diharapkan mampu meningkatkan motivasi Wajib Pajak untuk taat pajak serta mengurangi tingkat kecurangan dalam melaporkan, menyetorkan dan membayar kewajiban pajaknya kepada negara. Berdasarkan uraian tersebut, maka hipotesis pertama dalam penelitian ini sebagai berikut.

$\mathrm{H}_{1}$ : Religiusitas berpengaruh positif terhadap kepatuhan pajak.

Kepercayaan pada aparat merupakan keyakinan akan kemampuan, kinerja dan pelayanan aparat. Kepercayaan didukung dari integritas seseorang atau badan dalam menjalankan tugas dan tanggung jawabnya. Terkait masih adanya kasus gratifikasi yang dilakukan aparat pajak membuat masyarakat kurang percaya dengan pengelolaan pajak oleh aparat, sehingga menurunkan kredibilitas pelayanan pajak. Kepercayaan pada aparat merupakan faktor 
motivasional yang timbul dari dalam diri Wajib Pajak untuk lebih patuh terhadap pajak guna meningkatkan kesejahteraan masyarakat.

Bentuk kepercayaan aparat dapat dilihat dari kemampuan mengenai pengetahuan dan pengalaman serta pelayanan yang sesuai dengan sistem dan hukum pajak yang berlaku. Aparat diharapkan memberikan pelayanan yang efisien, efektif, jujur dan berintergritas kepada Wajib Pajak. Pelayanan perpajakan secara optimal yang dilaksanakan oleh aparat pajak meningkatkan kepercayaan Wajib Pajak. Penelitian yang dilakukan oleh Torgler (2007) menyatakan bahwa hubungan antara Wajib Pajak dengan negara memiliki ikatan emosional dan loyalitas. Sehingga penelitiannya menyatakan bahwa kepercayaan terhadap negara berpengaruh positif terhadap dimensi moralitas kepatuhan pajak. Mahadianto \& Astuti (2017) menjelaskan bahwa kepercayaan kepada otoritas berpengaruh positif terhadap kepatuhan pajak sukarela. Variabel kunci dari tingkat kepercayaan ini ialah kemampuan aparat yang handal dalam bidangnya, pelayanan yang berkualitas dan berintegritas. Berdasarkan uraian tersebut, maka hipotesis kedua dalam penelitian ini sebagai berikut.

$\mathrm{H}_{2}$ : Tingkat kepercayaan kepada aparat pajak berpengaruh positif terhadap kepatuhan pajak.

Teori motivasi dua faktor dikembangkan oleh Frederic Herzberg dan rekan-rekan pada tahun 1959, kedua faktor meliputi faktor intrinsik-ekstrinsik atau dikenal dengan faktor motivator-hygiene. Faktor hygiene bersifat ekstrinsik yang bersumber dari luar diri individu yang turut menentukan perilaku seseorang, faktor ini akan mencegah perilaku negatif atau ketidakpuasan. Aspekaspek hygiene meliputi: imbalan, hubungan sosial maupun status. Faktor hygiene dalam kepatuhan pajak berkaitan dengan tingkat pendidikan.

Pendidikan merupakan sebuah proses dengan cara atau metode tertentu sehingga individu dapat memperoleh pengetahuan atau pemahaman terhadap cara bertingkah laku. Tingkat pendidikan berkaitan dengan jenjang pendidikan. Semakin tinggi jenjang pendidikan yang dimiliki Wajib Pajak akan memberikan kemampuan untuk memahami ketentuan dan peraturan perpajakan yang berlaku. Rata-rata jenjang pendidikan Wajib Pajak di Indonesia yaitu SMA/Sederajat, D3, S1, S2, S3 dan lain sebagainya. Pendidikan diharapkan mampu menciptakan kedewasaan dan kesadaran individu akan kewajiban sebagai anggota masyarakat yang memiliki peran sebagai pemimpin organisasi, tokoh masyarakat maupun pendukung pembangunan masyarakat dan negara baik secara ekonomi, sosial maupun politik (FIP-UPI, 2007:2).

Menurut Jackson \& Milliron (1986), pendidikan yang tinggi akan membantu Wajib Pajak dalam memahami dan mematuhi undang-undang perpajakan. Tingkat pendidikan diharapkan meningkatkan motivasi Wajib Pajak akan kewajibannya. Hasil penelitian Maryati (2014) menemukan bahwa tingkat pendidikan berpengaruh positif terhadap kepatuhan pajak.

Tingkat pendidikan yang tinggi merupakan cerminan dari pengetahuan yang dimiliki seseorang. Kesadaran akan pengalaman yang dimiliki individu akan menghasilkan memotivasi tindakan Wajib Pajak akan kewajiban pajaknya. Berdasarkan uraian tersebut, maka hipotesis ketiga dalam penelitian ini sebagai berikut.

$\mathrm{H}_{3}$ : Tingkat pendidikan berpengaruh positif terhadap kepatuhan pajak. 
Pengetahuan pajak yang baik mampu memberikan edukasi kepada Wajib Pajak mengenai peraturan-peraturan yang berlaku. Pengetahuan dalam menjalankan tanggung jawabnya kepada negara. Pengetahuan pajak merupakan faktor motivasional Wajib Pajak untuk meminimalisir tindakan curang Wajib Pajak dalam membayar kewajiban utang pajaknya. Ketidaktahuan masyarakat akan pengetahuan perpajakan, menimbulkan ketidakpedulian Wajib Pajak terhadap kewajibannya melaporkan dan membayar pajak, sehingga akan mengurangi pendapatan kas negara. Peningkatan pengetahuan perpajakan dalam dilakukan dengan sosialisasi perpajakan di masyarakat.

Wardani \& Wati (2018) menyatakan bahwa pengetahuan perpajakan berpengaruh positif terhadap kepatuhan pajak. Witono (2008) juga menyatakan bahwa pengetahuan perpajakan berpengaruh positif terhadap kepatuhan pajak. Pentingnya pengetahuan perpajakan akan membantu meningkatkan kepatuhan pajaknya dan menyadarkan Wajib Pajak akan pentingnya melakukan perpajakan sesuai Undang-Undang Perpajakan. Jika Wajib Pajak tidak mengetahui pengetahuan perpajakan maka bisa terjadi tindakan penyelewengan yang dilakukan oleh Wajib Pajak. Berdasarkan uraian, maka hipotesis keempat dalam penelitian ini sebagai berikut.

$\mathrm{H}_{4}$ : Pengetahuan perpajakan berpengaruh positif terhadap kepatuhan pajak.

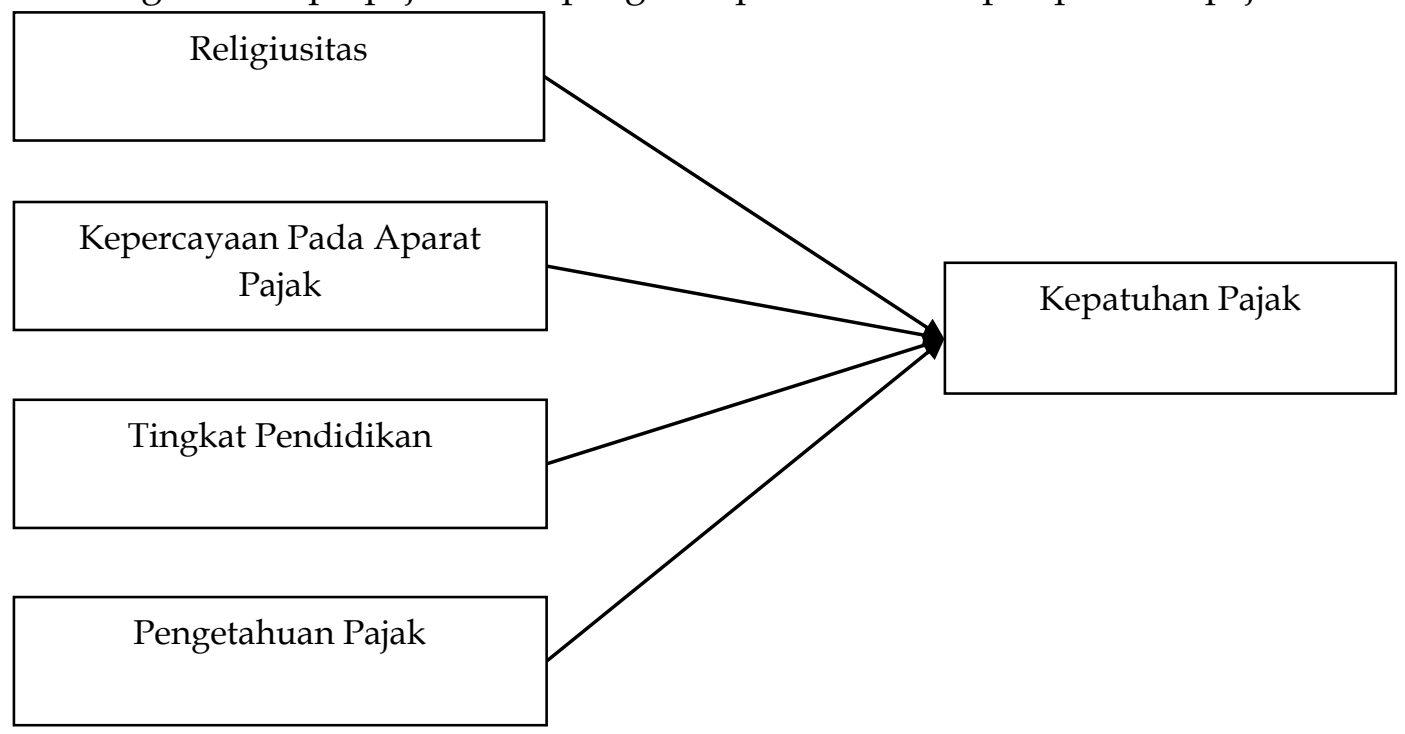

\section{Gambar 1. Model Peneltian}

Sumber: Data Penelitian, 2019

\section{METODE PENELITIAN}

Penelitian ini dilakukan pada Wajib Pajak Orang Pribadi Non Karyawan di KPP Pratama Malang Selatan. Dikarenakan jumlah objek penelitian yang besar maka jumlah sampel dalam penelitian ini ditentukan dengan menggunakan rumus Slovin menurut Enterprise (2014, p. 9), yaitu sebagai berikut

$$
n=\frac{N}{1+\left(N x\left(e^{2}\right)\right.} n=\frac{N}{1+\left(N x\left(e^{2}\right)\right.}
$$


Keterangan:

$\mathrm{n}$ : Ukuran sampel

$\mathrm{N}$ : Ukuran populasi

e : persentasi kesalahan pengambilan sampel yang dapat ditoleransi (margin of error).

Margin of error yang digunakan dalam penelitian ini sebesar $10 \%$ dari populasi yang ada menurut Suharyadi \& Purwanto (2016) sehingga sampel penelitian dapat dihitung sebagai berikut.

$$
\begin{aligned}
& \mathrm{n}=\frac{25,411}{1+\left(25,411 \times(0,1)^{2}\right) 1+\left(25,411 \times(0,1)^{2}\right)} \\
& \mathrm{n}=99,60801223 \\
& \mathrm{n}=100 \text { (dibulatkan). }
\end{aligned}
$$

Berdasarkan perhitungan menggunakan rumus Slovin, jumlah sampel penelitian sebanyak 100 responden. Teknik pengambilan sampel menggunakan accidental sampling, yaitu pengambilan sampel yang secara kebetulan ditemui dan memenuhi syarat untuk dijadikan sumber data (Siyoto \& Sodik, 2015). Teknik sampling ini termasuk dalam sampling non probabilitas yang mana teknik pengambilan sampel yang sederhana dalam pengambilan data dan dalam pengukurannya. Pengukuran sampel pada penelitian ini memiliki kriteria yaitu, responden yang digunakan sebagai sampel dalam penelitian ini ialah Wajib Pajak Orang Pribadi Non Karyawan yang menjalankan suatu usaha atau pekerjaan bebas yang memiliki NPWP dan terdaftar di KPP Pratama Malang Selatan sebagai syarat objektif.

Metode pengumpulan data dilakukan dengan penyebaran instrumen kuesioner kepada responden (Wajib Pajak Orang Pribadi) di KPP Pratama Malang Selatan. Di bagian identitas responden untuk pertanyaan terkait variabel tingkat pendidikan menggunakan skala ordinal. Masing-masing kuesioner terdiri dari 5 (lima) alternatif jawaban yang tersedia dengan diberi bobot nilai (skor) dengan menggunakan skala Likert.

Pengujian hipotesis dalam penelitian ini menggunakan analisis regresi linear berganda. Metode analisis linear berganda merupakan pengujian hipotesis dengan menunjukkan keterkaitan antara dua variabel atau lebih sehingga menunjukkan arah variabel dependen maupun independen. Metode yang digunakan dalam penelitian ini ialah analisis regresi linear berganda dikarenakan terdapat lebih dari satu variabel independen. Untuk membuktikan hipotesis, peneliti menggunakan uji statistik uji F dan uji t. Model regresi linear berganda ditunjukkan melalui persamaan berikut ini (Usman \& Akbar, 2009).

$$
\mathrm{Y}=\sigma+\mathrm{b} 1 \mathrm{X} 1+\mathrm{b} 2 \mathrm{X} 2+\mathrm{b} 3 \mathrm{X} 3+\mathrm{b} 4 \mathrm{X} 4+\varepsilon
$$

Keterangan:

$$
\begin{array}{ll}
\mathrm{Y} & =\text { Kepatuhan Pajak Orang Pribadi } \\
\sigma & =\text { Konstanta } \\
\mathrm{b}_{1}-\mathrm{b}_{4} & =\text { Koefisien regresi } \\
\mathrm{X}_{1} & =\text { Religiusitas } \\
\mathrm{X}_{2} & =\text { Tingkat Kepercayaan pada Aparat Pajak } \\
\mathrm{X}_{3} & =\text { Tingkat Pendidikan } \\
\mathrm{X}_{4} & =\text { Pengetahuan Pajak } \\
\varepsilon & =\text { Error }
\end{array}
$$


HASIL DAN PEMBAHASAN

Berdasarkan Tabel 1, terdapat 57 responden atau $57 \%$ dengan pendidikan terakhir S1, terdapat 25 responden atau $25 \%$ dengan pendidikan terakhir SMA/Sederajat, lalu terdapat 9 responden atau $9 \%$ dengan pendidikan terakhir S2, dan D3.

Tabel 1. Deskripsi Variabel Tingkat Pendidikan

\begin{tabular}{lll}
\hline Pendidikan & Jumlah & Persentase \\
\hline SMA/Sederajat & 25 & $25 \%$ \\
Diploma (D1/D2/D3) & 9 & $9 \%$ \\
S1 & 57 & $57 \%$ \\
S2 & 9 & $9 \%$ \\
Jumlah & 100 & $100 \%$ \\
\hline
\end{tabular}

Sumber: Data Penelitian, 2019

Analisis statistik deskriptif digunakan untuk memperoleh gambaran mengenai karakteristik responden penelitian dari beberapa aspek, seperti: umur, jenis kelamin, pendidikan, dan masa kerja. Analisis deskriptif ini dilakukan dengan analisis distribusi frekuensi dengan menghitung frekuensi atau jumlah dan persentase dari masing-masing aspek yang diukur.

Analisis statistic deskriptif juga digunakan untuk menggambarkan persepsi responden atas indikator-indikator setiap variabel penelitian, berdasarkan kecenderungan tanggapan responden terhadap butir-butir pernyataan dalam instrumen penelitian. Deskripsi setiap indikator disajikan dalam nilai frekuensi dan rata-rata. Dengan analisis deskriptif ini diperoleh gambaran persepsi responden terhadap indikator-indikator yang merefleksikan variabel penelitian.

\section{Tabel 2. Statistik Deskriptif}

\begin{tabular}{lrrrrr}
\hline & $\begin{array}{c}\text { Religiusitas } \\
(\mathrm{X} 1)\end{array}$ & $\begin{array}{c}\text { Kepercayaan } \\
\text { pada Aparat } \\
(\mathrm{X} 2)\end{array}$ & $\begin{array}{c}\text { Tingkat } \\
\text { Pendidikan } \\
(\mathrm{X} 3)\end{array}$ & $\begin{array}{c}\text { Pengetahuan } \\
\text { Perpajakan } \\
(\mathrm{X} 4)\end{array}$ & $\begin{array}{r}\text { Kepatuhan } \\
\text { Pajak (Y) }\end{array}$ \\
\hline $\mathrm{N} \quad$ Valid & 100 & 100 & 100 & 100 & 100 \\
$\quad$ Missing & 0 & 0 & 0 & 0 & 0 \\
Mean & 4,2700 & 3,8500 & 2,6462 & 3,9730 & 4,1127 \\
Median & 4,4000 & 3,8333 & 3,1623 & 4,0000 & 4,0000 \\
Mode & 4,80 & 4,00 & 3,16 & $3,90 \mathrm{a}$ & 4,00 \\
Std. Deviation &, 63397 &, 61065 & 1,10778 &, 46750 &, 51800 \\
Minimum & 2,40 & 2,00 & 1,00 & 2,90 & 2,91 \\
Maximum & 5,00 & 5,00 & 4,61 & 5,00 & 5,00 \\
a. Multiple modes exist. The smallest value is shown & & & \\
\hline
\end{tabular}

Sumber: Data Penelitian, 2019

Pengujian validitas dilakukan dengan mengukur korelasi antar skor item instrumen dalam suatu faktor dengan skor total. Bila korelasi tiap faktor tersebut positif dan besarnya lebih dari 0,3 maka faktor tersebut merupakan konstruk yang kuat. Jadi berdasarkan analisis faktor dapat disimpulkan bahwa instrumen tersebut memiliki validitas konstruksi yang baik. Tabel 3, menyajikan hasil uji validitas instrumen penelitian.

Tabel 3, menunjukkan bahwa seluruh indikator pernyataan dalam variabel dependen memiliki korelasi tiap faktor lebih dari 0,3 sehingga seluruh indikator tersebut telah memenuhi syarat uji validitas. 
Tabel 3. Uji Validitas

\begin{tabular}{|c|c|c|c|c|}
\hline Variabel & Item & r hitung & $\mathrm{r}$ tabel & Keterangan \\
\hline \multirow{11}{*}{$\begin{array}{l}\text { Kepatuhan } \\
\text { Perpajakan }\end{array}$} & Y.1 & 0,536 & 0,361 & Valid \\
\hline & Y.2 & 0,719 & 0,361 & Valid \\
\hline & Y.3 & 0,839 & 0,361 & Valid \\
\hline & Y.4 & 0,836 & 0,361 & Valid \\
\hline & Y.5 & 0,827 & 0,361 & Valid \\
\hline & Y.6 & 0,736 & 0,361 & Valid \\
\hline & Y.7 & 0,616 & 0,361 & Valid \\
\hline & Y.8 & 0,684 & 0,361 & Valid \\
\hline & Y.9 & 0,869 & 0,361 & Valid \\
\hline & Y.10 & 0,879 & 0,361 & Valid \\
\hline & Y.11 & 0,826 & 0,361 & Valid \\
\hline \multirow{5}{*}{ Religiusitas } & X1.1 & 0,932 & 0,361 & Valid \\
\hline & X1.2 & 0,978 & 0,361 & Valid \\
\hline & X1.3 & 0,969 & 0,361 & Valid \\
\hline & X1.4 & 0,906 & 0,361 & Valid \\
\hline & X1.5 & 0,924 & 0,361 & Valid \\
\hline \multirow{6}{*}{$\begin{array}{l}\text { Kepercayaan } \\
\text { Terhadap Aparat }\end{array}$} & X2.1 & 0,897 & 0,361 & Valid \\
\hline & X2.2 & 0,909 & 0,361 & Valid \\
\hline & $X 2.3$ & 0,923 & 0,361 & Valid \\
\hline & $X 2.4$ & 0,871 & 0,361 & Valid \\
\hline & $X 2.5$ & 0,784 & 0,361 & Valid \\
\hline & X2.6 & 0,839 & 0,361 & Valid \\
\hline \multirow{10}{*}{$\begin{array}{l}\text { Pengetahuan } \\
\text { Perpajakan }\end{array}$} & $X 4.1$ & 0,633 & 0,361 & Valid \\
\hline & $X 4.2$ & 638 & 0,361 & Valid \\
\hline & $X 4.3$ & 715 & 0,361 & Valid \\
\hline & $X 4.4$ & 420 & 0,361 & Valid \\
\hline & $X 4.5$ & 601 & 0,361 & Valid \\
\hline & $X 4.6$ & 610 & 0,361 & Valid \\
\hline & $X 4.7$ & 802 & 0,361 & Valid \\
\hline & X4.8 & 756 & 0,361 & Valid \\
\hline & $X 4.9$ & 669 & 0,361 & Valid \\
\hline & $X 4.10$ & 758 & 0,361 & Valid \\
\hline
\end{tabular}

Sumber: Data Penelitian, 2019

Reliabilitas menunjukkan sejauh mana suatu pengukuran dapat menghasilkan data yang sama (konsisten) bila dilakukan pengukuran beberapa kali terhadap obyek yang sama. Nilai suatu instrumen dikatakan reliabel bila nilai Cronbach's Alpha $\geq 0,6$. Tabel 4, menyajikan hasil uji reliabilitas instrumen penelitian

\section{Tabel 4. Uji Reliabilitas}

\begin{tabular}{lccc}
\hline \multicolumn{1}{c}{ Variabel } & Cronbach Alpha & Batas Reabilitas & Keterangan \\
\hline Kepatuhan Pajak & 0,926 & 0,6 & Reliabel \\
Religiusitas & 0,965 & 0,6 & Reliabel \\
Kepercayaan & 0,936 & 0,6 & Reliabel \\
$\begin{array}{l}\text { Terhadap Aparat } \\
\begin{array}{l}\text { Pengetahuan } \\
\text { Perpajakan }\end{array}\end{array}$ & 0,855 & 0,6 & Reliabel \\
Sumber: Data Penelitian, 2019 & & &
\end{tabular}

Sumber: Data Penelitian, 2019 
Pada penelitian ini pengujian normalitas menggunakan uji Normal Kolmogorov-Smirnov. Berdasarkan hasil uji normalitas, dapat disimpulkan bahwa model regresi ini berdistribusi normal, karena memiliki nilai sig. (2-tailed) sebesar 0,081, lebih besar dari 0,05. Kemudian berdasarkan hasil uji multikolinearitas, diketahui bahwa tolerance dan VIF dari variabel Religiusitas $\left(X_{1}\right)$ sebesar 0,762 dan 1,312, variabel Kepercayaan Terhadap Aparat $\left(X_{2}\right)$ sebesar 0,603 dan 1,659, variabel Tingkat Pendidikan $\left(X_{3}\right)$ sebesar 0,980 dan 1,021 serta untuk variabel Pengetahuan Perpajakan $\left(X_{4}\right)$ sebesar 0,716 dan 1,396. Oleh karena itu, dapat disimpulkan bahwa persamaan model regresi tidak mengandung masalah multikolinearitas yang artinya tidak ada korelasi antar variabel-variabel bebas sehingga layak digunakan dan dianalisis ke tahap selanjutnya karena hasil menunjukkan> 0,1 dari batas tolerance dan nilai VIF menunjukkan hasil kurang dari 10. Hasil uji heteroskedastisitas pada penelitian ini dapat disimpulkan bahwa tidak terjadi heteroskedasitas pada variabel Religiusitas, Kepercayaan Terhadap Aparat, dan Pengetahuan Pajak dikarenakan titik pola pada gambar yang menyebar dan tidak menghasilkan pola berbentuk (bergelombang, melebar atau menyempit).

\section{Tabel 5. Uji Linear Berganda}

\begin{tabular}{|c|c|c|c|c|c|c|}
\hline \multirow{2}{*}{\multicolumn{2}{|c|}{ Model }} & \multicolumn{2}{|c|}{$\begin{array}{l}\text { Unstandardized } \\
\text { Coefficients }\end{array}$} & \multirow{2}{*}{$\begin{array}{l}\text { Standardized } \\
\text { Coefficients } \\
\text { Beta } \\
\end{array}$} & \multirow[t]{2}{*}{$\mathrm{t}$} & \multirow[t]{2}{*}{ Sig. } \\
\hline & & $\mathrm{B}$ & Std. Error & & & \\
\hline \multirow[t]{5}{*}{1} & (Constant) & ,382 & 361 & & 1,059 & 292 \\
\hline & Religiusitas (X1) & ,343 & ,063 & ,420 & 5,419 & 000 \\
\hline & $\begin{array}{l}\text { Kepercayaan pada } \\
\text { Aparat }(X 2)\end{array}$ & 221 & ,074 & 260 & 2,986 & 004 \\
\hline & $\begin{array}{l}\text { Tingkat } \\
\text { Pendidikan (X3) }\end{array}$ & 070 & ,032 & 151, & 2,202 & 030 \\
\hline & $\begin{array}{l}\text { Pengetahuan } \\
\text { Perpajakan (X4) }\end{array}$ & ,309 & 089 & 279, & 3,482 & 001 \\
\hline \multicolumn{7}{|c|}{ a. Dependent Variable: Kepatuhan Pajak (Y) } \\
\hline
\end{tabular}

Sumber: Data Penelitian, 2019

Berdasarkan hasil analisa data pada Tabel 6, diketahui nilai $\mathrm{R}$ square sebesar 0,546 atau sebesar $54,6 \%$ merupakan kontribusi dari religiusitas $\left(X_{1}\right)$, kepercayaan pada aparat $\left(X_{2}\right)$, tingkat pendidikan $\left(X_{3}\right)$ dan pengetahuan perpajakan $\left(\mathrm{X}_{4}\right)$ terhadap kepatuhan wajib pajak $(\mathrm{Y})$. Artinya perubahan kepatuhan wajib pajak oleh Wajib Pajak Orang Pribadi Non Karyawan di KPP Pratama Malang Selatan $(Y)$ yang ditimbulkan oleh religiusitas $\left(X_{1}\right)$, kepercayaan pada aparat $\left(X_{2}\right)$, tingkat pendidikan $\left(X_{3}\right)$ dan pengetahuan perpajakan $\left(X_{4}\right)$ secara simultan sebesar $54,6 \%$. Sedangkan sisanya sebesar $100 \%-54,6 \%=45,4 \%$ merupakan faktor kepatuhan pajak yang disebabkan oleh variabel lain yang tidak diteliti atau di luar penelitian ini.

Tabel 6. Uji Koefisien Determinasi

\begin{tabular}{lllll}
\hline Model & $\mathrm{R}$ & $\mathrm{R}$ Square & $\begin{array}{l}\text { Adjusted } \mathrm{R} \\
\text { Square }\end{array}$ & Std. Error of the Estimate \\
\hline 1 &, $751^{\mathrm{a}}$ &, 564 &, 546 &, 34906
\end{tabular}

a. Predictors: (Constant), Pengetahuan Perpajakan $\left(\mathrm{X}_{4}\right)$, Tingkat Pendidikan $\left(\mathrm{X}_{3}\right)$, Religiusitas $\left(\mathrm{X}_{1}\right)$, Kepercayaan pada Aparat $\left(\mathrm{X}_{2}\right)$ Sumber: Data Penelitian, 2019 
Uji t digunakan untuk menunjukkan pengaruh semua variabel independen secara parsial pada variabel dependen. Kriteria pengujian yaitu apabila nilai signifikansi $<0,0_{5}$ maka $\mathrm{H}_{0}$ ditolak dan $\mathrm{H}_{1}$ diterima. Sebaliknya, jika nilai signifikansi $>0,05$ maka $\mathrm{H}_{0}$ diterima dan $\mathrm{H}_{1}$ ditolak. Hasil uji $\mathrm{t}$ dapat dilihat pada Tabel 5.

Hasil analisis data menunjukkan bahwa variabel religiusitas mempunyai nilai $t 5,419$ dan signifikan t 0,000. Nilai signifikan $t$ disini lebih kecil dari a $5 \%$ $(0,000 \leq 0,05)$. Indikator yang berpengaruh dalam variabel ini adalah keyakinan (belief) sedangkan indikator yang kurang berpengaruh adalah pengetahuan (knowledge). Dengan demikian, dapat ditarik kesimpulan bahwa terdapat pengaruh yang signifikan antara religiusitas terhadap kepatuhan pajak untuk subjek penelitian Wajib Pajak Orang Pribadi di KPP Pratama Malang Selatan.

Religiusitas termasuk katagori faktor motivasional dalam teori motivasi dua faktor karena Wajib Pajak diharapkan patuh membayar pajak timbul dari keinginan diri sendiri bukan dengan keterpaksaan. Jika faktor religiusitas tidak ada maka akan membuat perilaku menyimpang karena religiusitas berperan penting dalam memotivasi secara internal perilaku Wajib Pajak. Religiusitas akan memotivasi Wajib Pajak untuk bersikap jujur, memiliki kesadaran serta memiliki hasrat yang tinggi untuk membayar pajak.

Perlunya pengajaran oleh pemuka agama mengenai hak dan kewajiban manusia dalam negara, sehingga Wajib Pajak memahami perannya sebagai warga negara. Dorongan keyakinan dari dalam diri meneguhkan kepercayaan agama yang dianut dan perintah-perintahnya sehingga mendukung perilaku kepatuhan pajak.

Hasil analisis data menunjukkan bahwa variabel kepercayaan pada aparat memiliki nilai t 2,986 dan signifikan t 0,004 . Nilai signifikan $t$ disini lebih kecil dari a $5 \%(0,004 \leq 0,05)$. Berdasarkan hasil analisis data, dapat ditarik kesimpulan bahwa terdapat pengaruh yang signifikan antara kepercayaan pada aparat terhadap kepatuhan pajak untuk subjek penelitian Wajib Pajak Orang Pribadi di KPP Pratama Malang Selatan.

Kepercayaan termasuk faktor motivasional dalam teori motivasi dua faktor. Kepercayaan pada aparat dapat dijelaskan sebagai faktor motivasional karena kepercayaan yang berasal dari dalam diri sendiri dan merupakan faktor penting dalam mencapai kepatuhan pajak. Kepercayaan akan membentuk kejujuran dan kesadaran yang memotivasi Wajib Pajak untuk patuh dalam membayar maupun melaporkan pajak. Berdasarkan teori motivasi, kepercayaan pada aparat berasal dari diri sendiri dan terkadang didorong oleh lingkungan sekitar, hanya pada saat pengambilan keputusan untuk tetap mempercayai aparat berasal dari dalam diri.

Indikator yang berpengaruh dan kurang berpengaruh dalam variabel penelitian ini sama yaitu niat baik. Hal ini menyakini Wajib Pajak bahwa aparat memiliki kinerja yang berkualitas. Walaupun terjadi beberapa kasus korupsi dibidang pajak namun Wajib Pajak di KPP Pratama Malang Selatan tetap memiliki kepercayaan tinggi kepada aparat dalam menjalankan tugas dan tanggung jawabnya. Kepercayaan pada aparat akan meningkatkan penerimaan pajak melalui iuran yang disetorkan oleh Wajib Pajak. Kepercayaan terhadap 
aparat meliputi beberapa hal, yakni: kualitas, kehandalan, keterbukaan, integritas, dan kemampuan aparat.

Hasil analisis data menunjukkan bahwa variabel tingkat pendidikan mempunyai nilai $t 2,202$ dan signifikan $t$ 0,030. Nilai signifikan $t$ disini lebih kecil dari a $5 \%(0,030 \leq 0,05)$. Dengan demikian, dapat ditarik kesimpulan bahwa terdapat pengaruh yang signifikan antara tingkat pendidikan terhadap kepatuhan pajak untuk subjek penelitian Wajib Pajak Orang Pribadi di KPP Pratama Malang Selatan.

Tingkat pendidikan dalam penelitian ini merupakan pendidikan formal yang diterapkan oleh pemerintah dan disahkan oleh Dinas Pendidikan. Tingkat pendidikan termasuk dalam faktor hygiene atau motivasi dari luar diri yang dipengaruhi oleh lingkungan dan mencegah terjadinya ketidakpuasan. Tingkat pendidikan yang dipengaruhi dari luar diri melalui lingkungan sosial akan mendorong Wajib Pajak untuk taat pajak. Taat pajak akan terbentuk dengan memahami dan melaksanakan ketentuan-ketentuan serta memahami sanksi yang berlaku apabila Wajib Pajak tidak menjalankan kewajibannya dengan patuh.

Tingkat pendidikan yang tinggi juga mampu memberikan edukasi dan pemahaman secara tidak langsung kepada orang-orang disekitarnya yang minim akan pengetahuan mengenai pajak. Pendidikan yang tinggi akan membantu Wajib Pajak dalam memahami dan mematuhi undang-undang perpajakan, dimana Wajib Pajak akan lebih memahami sanksi yang diberikan jika melakukan kelalaian atau kecurangan dalam membayar maupun melaporkan pajak, karena akan memudahkan penghindaran maupun penyelewengan pajak (Jackson \& Milliron, 1986). Berdasarkan penelitian ini dapat disimpulkan bahwa semakin tinggi tingkat pendidikan maka semakin tinggi tingkat kepatuhan pajak.

Hasil analisis data menunjukkan bahwa variabel pengetahuan perpajakan memiliki nilai t 3,482 dan signifikan $t$ 0,001. Nilai signifikan $t$ disini lebih kecil dari a $5 \%(0,001 \leq 0,05)$. Berdasarkan hasil analisis data, dapat disimpulkan bahwa terdapat pengaruh yang signifikan antara pengetahuan perpajakan terhadap kepatuhan pajak untuk subjek penelitian Wajib Pajak Orang Pribadi di KPP Pratama Malang Selatan.

Berkaitan dengan teori motivasi dua faktor, pengetahuan perpajakan termasuk dalam faktor motivasional, dimana motivasi perilaku berasal dari sifat dan motif dalam diri sendiri. Faktor motivasional yang berkaitan dengan pengetahuan perpajakan mendukung adanya kepatuhan pajak. Pengetahuan perpajakan akan membentuk kesadaran Wajib Pajak akan pentingnya pajak sehingga menciptakan hasrat yang tinggi untuk membayar pajak. Jika Wajib Pajak memiliki pengetahuan yang memadai mengenai tujuan dan fungsi perpajakan maka Wajib Pajak akan memiliki kesadaran dan sikap peduli terhadap pajak serta tepat waktu sebagai bentuk kepatuhan pajaknya. Semakin tinggi pengetahuan perpajakan maka semakin tinggi tingkat kepatuhan pajak.

Diperlukannya peran pemerintah yang bekerja sama dengan Wajib Pajak maupun aparat pajak dalam meningkatkan pengetahuan pajak. Salah satu yang bisa dilakukan adalah dengan mengadakan sosialisasi mengenai tata cara pengisian SPT, pengetahuan dasar perpajakan maupun manfaat membayarkan pajak. Pengetahuan pajak dapat diperoleh baik secara formal melalui sekolah 
atau universitas terkait perpajakan maupun secara informal dengan mengikuti brevet, seminar maupun pada saat sosialisasi pajak sehingga mengurangi keterlambatan pembayaran maupun pelaporan pajak.

\section{SIMPULAN}

Hasil yang ditunjukkan dari penelitian ini serta teori-teori yang digunakan dapat mendukung hasil penelitian dan memberikan pemahaman mengenai pengaruh religiusitas, kepercayaan pada aparat, tingkat pendidikan dan pengetahuan pajak berpengaruh positif terhadap kepatuhan pajak wajib pajak orang pribadi non karyawan di KPP Pratama Malang Selatan. Penelitian ini dapat memberikan bukti secara empiris serta mengkonfirmasi teori motivasi dua faktor mendukung kepatuhan pajak. Teori motivasi dua faktor merupakan keyakinan dasar atau motivasi Wajib Pajak dalam membayar pajak yang berkaitan dengan kepuasan dan ketidakpuasan. Terdapat dua faktor yang mempengaruhi motivasi ini yaitu faktor motivasional berkaitan dengan variabel religiusitas dan pengetahuan perpajakan. Sedangkan faktor hygiene berkaitan dengan variabel kepercayaan pada aparat dan tingkat pendidikan. Keterbatasan dalam penelitian ini adalah terdapat indikator penelitian yang hanya mencangkup satu butir pertanyaan, seperti pada variabel religiusitas. Hal ini menjadi pertimbangan mengenai kedalaman dan kesinambungan terkait pertanyaan dan indikator penelitian.

Berdasarkan hasil penelitian, disarankan bagi KPP Pratama Malang Selatan untuk melakukan kerjasama dengan pemuka agama untuk memberikan pemahaman mengenai pentingnya membayar pajak, sesuai dengan ajaran dan perintah agama. Aparat pajak di KPP Pratama Malang Selatan harus terus melakukan peningkatan integritas melalui kualitas pelayanan maupun kinerja yang dapat dipertanggungjawabkan, serta melakukan sosialisasi mengenai pentingnya pajak sejak dini kepada Wajib Pajak yaitu melakukan kerjasama dengan akademisi untuk memberikan pengetahuan pajak kepada Wajib Pajak.

\section{REFERENSI}

Ariani, M. Z. (2016). Pengaruh Sosialisasi, Sanksi , dan Kepercayaan Terhadap Kepatuhan Wajib Pajak dalam Membayar Pajak PPh Pasal 21. Jurnal Riset Akuntansi Dan Perpajakan JRAP, 3(2), 161-175. http://garuda.ristekdikti.go.id/documents/detail/961127\%0Ameiliyah_ari ani@dsn.moestopo,depriswa@gmail.com,zulhawaty@uty.ac.id

Asshiddiqie, J. (2010). Konstitusi Ekonomi. Kompas.

Bayinah, A. N. (2015). Bayar Pajak Lebih Murah: Cara Tepat Dan Mudah Mengurangi Pajak dengan Zakat dan Sumbangan (Z. Simatur (ed.)). Visimedia Pustaka.

Dwi, W. R., \& Renny, W. (2017). Affecting compliant with the willingness to Pay Tax As An Intervening Variable Factor (Studies on The Taxpayer Owners of SMEs in Pontianak KPP). Journal of Advances in Humanities and Social Sciences, 3(3), 152-162. https:/ / doi.org/10.20474/jahss-3.3.3

Faisal, G. S. (2009). How To Be A Smarter Tax payer: (Bagaimana menjadi wajib pajak yang lebih cerdas). Grasindo.

Ghoni, H. A. (2012). Pengaruh Motivasi dan Pengetahuan Wajib Pajak Terhadap Kepatuhan Wajib Pajak Daerah. 1.

Jackson, B. R., \& Milliron, V. C. (1986). Tax Compliance Research: Findings, 
Problems, and Prospects. Journal of Accounting Literature. https://doi.org/10.3868/ s110-003-014-0039-x

Mahadianto, M. Y., \& Astuti, A. D. (2017). Previllage Tax Payer, Sosialisasi Pajak Dan Kepercayaan Pada Otoritas Pajak Terhadap Kepatuhan. Jurnal Kajian Akuntansi, 1(1), 77-86. https://doi.org/10.33603/jka.v1i1.525

Manalu, D., Nasir, A., \& Sofyan, A. (2016). Pengaruh Kesadaran, Sanksi Perpajakan, Tingkat Pendidikan Dan Pelayanan Fiskus Terhadap Kepatuhan Wajib Pajak Dalam Melaporkan Pajak Restoran Di Kota Pekanbaru. Jurnal Online Mahasiswa Fakultas Ekonomi Universitas Riau, 3(1), 822-836.

Maryati, E. (2014). Pengaruh Sanksi Pajak, Motivasi Dan Tingkat Pendidikan Terhadap Kepatuhan Wajib Pajak. Jurnal Umrah.

Noermijati. (2013). Kajian Tentang Aktualisasi Teori Herzberg, Kepuasan Kerja, dan Kinerja Spiritual Manajer Operasional. UB Press.

Pasaribu, G. F., \& Tjen, C. (2016). Dampak Faktor-Faktor Demografi Terhadap Kepatuhan Perpajakan di Indonesia. Berkala Akuntansi Dan Keuangan Indonesia, 1(2), 145-162. https:/ / doi.org/10.20473/ baki.v1i2.2696

Ratmono, D., \& Cahyonowati, N. (2016). Kepercayaan Terhadap Otoritas Pajak Sebagai Pemoderasi Pengaruh Deterrence Factors Terhadap Kepatuhan Wajib Pajak Pribadi. Jurnal Akuntansi Indonesia, 2(1), 1. https://doi.org/10.30659/jai.2.1.1-15

Siahaan, F. O. (2005). Faktor - Faktor Yang Mempengaruhi Perilaku Kepatuhan Tax Professional Dalam Pelaporan Pajak Badan Pada Perusahaan Industri Manufaktur Di Surabaya. UNIVERSITAS AIRLANGGA.

Siyoto, S., \& Sodik, M. A. (2015). Dasar Metodologi Penelitian. Literasi Media Publishing.

Sondakh, J. J. (2017). Behavioral intention to use e-tax service system: An application of technology acceptance model. European Research Studies Journal, 20(2), 48-64.

Suharyadi, \& Purwanto, S. K. (2016). Statistika untuk Ekonomi dan Keuangan Modern. In Statistika untuk Ekonomi dan Keuangan Modern Buku 2.

Torgler, B. (2007). Tax compliance and tax morale: A theoretical and empirical analysis. In Tax Compliance and Tax Morale: A Theoretical and Empirical Analysis.

Usman, H., \& Akbar, R. P. S. (2009). Pengantar Statistika. Bumi Aksara.

Wardani, D. K., \& Wati, E. (2018). Pengaruh Sosialisasi Perpajakan Terhadap Kepatuhan Wajib Pajak Dengan Pengertahuan Perpajakan Sebagai Variabel Intervening (Studi Pada Wajib Pajak Orang Pribadi Di KPP Pratama Kebumen). Nominal, Barometer Riset Akuntansi Dan Manajemen. https://doi.org/10.21831/nominal.v7i1.19358

Widagsono, S. (2017). Pengaruh Pengetahuan Perpajakan, Sanksi, dan Religiusitas Terhadap Kepatuhan Wajib Pajak (Studi Kasus Pada KPP Pratama Kepanjen).

Widodo, W. (2010). Moralitas, Budaya dan Kepatuhan Pajak. Alfabeta.

Witono, B. (2008). Peran Pengetahuan Pajak Pada Kepatuhan Wajib Pajak. Riset Akuntansi Dan Keuangan Indonesia. https://doi.org/10.23917/ reaksi.v7i2.2624

Yustina, L., Diatmika, I. P. G., \& Yasa, I. N. P. (2019). Pengaruh Tingkat 
Pendidikan, Kewajiban Moral Dan Sanksi Perpajakan Terhadap Kepatuhan Wajib Pajak Kendaraan Bermotor (Studi Pada Kantor Samsat Kabupaten Buleleng). JIMAT (Jurnal Ilmiah Mahasiswa Akuntansi S1), 10(2). https://doi.org/10.23887/jimat.v10i2.21557 